\title{
Mini Tinjauan Pemberdayaan Internet Sebagai Media Baru Dari Segi Plolitik, Ekonomi, dan Pendidikan
}

\author{
Farhan Lubis \\ Fakultas Ilmu Tarbiyah Dan Keguruan \\ Program Studi Pendidikan Matematika \\ Universitas Islam Negeri Sumatera Utara \\ Kec . Delitua, Kabupaten Deli Serdang, Sumatera Utara
}

\begin{abstract}
Abstrak
Media baru merupakan istilah yang sering dipakai untuk melainkannya dengan media tradisional. Garis batas antara media baru dengan media lama sulit ditentukan secara pasti tergantung dari sudut pandang seseorang. Internet dapat dikatakan sebagai awal dari era media baru karena internet sangat berbeda dengan media sebelumnya. Pada awalnya, aplikasi di internet hanya website dan email. Setelah itu muncul berbagai berbagai aplikasi atau media baru seperti web, facebook, instagram, twiter, line, vimeo, vevo, dan lain-lain. Jurnal ini semoga dapat menolong membatasi pemberdayaan internet dari segi politik, ekonomi, dan pendidikan. Pasalnya, keempat area tersebut telah memanfaatkan hampir semua media baru di internet. Dengan pelacakan kepustakaan (library research) dan dengan pelacakan jurnal-jurnal yang berkaitan (jurnal research). Dengan new media orang-orang dapat memanfatkan internet dengan sebaik-baiknya dan dengan new media dapat diperdayakan oleh semua ilmu baik ilmu politik, ekonomi dan pendidikan yang berhubungan dengan banyak bentuk kehidupan manusia guna menunjang aktifitas manusia baik dari segi politik, ekonomi, dan pendidikan.
\end{abstract}

Kata kunci : Media baru, internet, pemanfaatan, situs jejaring sosial.

\section{PENDAHULUAN}

Datangnya new media berhubungan dengan internet yang ada didunia ini.

Dahulu pada saat telepon masih menggunkan kabel orang tidak berfikir bahwa sekarang telepon sudah bisa tanpa menggunakan kabel bahkan sudah bisa menampakkan gambar, tidak sekedar suara Flew (2005:4). Faktanya internet berkembang pesat, awalnya digunakan untuk militer serta kesehatan dan juga situs, dan sekarang internet digunakan untuk banyak hal seperti youtube, instagram, facebook, game online, blog, website yang banyak digunakan sebagai hiburan semata.Handphone turunan saat ini 
juga sudah dilengkapi dengan Wi-Fi, Bluetooth, dan hotspot yang bertambah banyak sehingga semakin mudah bagi individu untuk mengarungi Internet.

Singkatnya, sekarang internet dapat mempersatu dunia, sehingga yang dahulu jauh sekarang sudah tidak jauh lagi. Bilamana dahulu orang yang berada di medan ingin mengirim kado atau surat ke Papua memerlukan waktu sampai seminggu atau dua minggu sampai kado atau surat itu diterima, saat ini lewat SMS, email atau surat elektronik itu bisa cepat diterima oleh orang yang ingin dikirimi kado atau surat. Bukan hanya untuk mengirim surat, internet juga dapat digunakan untuk kepentingan bisnis seperti jualan online, belanja online, dan transaksi online yang hanya bisa dilakukan dengan duduk di rumah saja. saat ini internet telah membuat perubahan diberbagai bidang di dunia.

Sebagian ahli setuju bahwa istilah media baru itu dipakai sebagai pembeda media tradisional (old media) dari new media (media baru). Contohya, bermain game pada puluhan tahun silam bermain game dapat dilakukan dengan teman dilapangan atau tempat lainnya yang dapat digunakan untuk bermain tetapi setelah ada internet bermain game dapat dilakukan dengan adanya game online yang dapat mengakses berbagai macam jenis permainan dan bukan hanya orang yang berada di Indonesia saja dapat mengaksesnya tetapi seluruh dunia juga bisa. Contoh lain, dulu orang harus kekantor pos atau meletakkan surat dalam botol lalu dibuang ke laut untuk mengirim surat dan itu memerlukan waktu yang lumayan lama seperti surat yang dikirim kekantor pos akan membutuhkan waktu tiga hari hingga seminggu agar surat dapat terkirim ke yang bersangkutan, tetapi dengan adanya internet surat dapat dikirim melalui email atau pesan yang ada di jejaring sosial. akan tetapi, tidaklah mudah untuk menggolongkan suatu media sebagai old media atau new media. sebagai contoh pemutar kaset atau laserdisc dianggap tua dibanding VCD (video compact disk) oleh karena itu VCD dapat dikatakan sebagai new media. Namun, VCD dianggap tua dibandingkan DVD (digital versatile disc) oleh karena itu apakah VCD itu termasuk old media? Sulit untuk dijawab.

Dalam pandangan lain, new media (media baru) itu disebut internet,hal ini dikarenakan media sekarang dilengkapi dengan berbagai fitur aplikasi sepeti facebook, instagram, twiter, game online, e-book, e-mail, blog dan lainnya. Diluar internet seperti komputer multi media, handphone,Wikipedia, SMS, DVD. Menurut Ensiklopedia yang ada diinternet menganggap yang cocok dijadikan sebagai contoh dari media baru adalah Wikipedia.

Situs dapat digunakan untuk apapun termasuk mencari ilmu pengetahuan, sebagai bahan pelajaran. Tetapi situs juga dapat merusak akhlak manusia terutama anak kecil seperti seringkali didalam situs menampilkan gambar-gambar porno. Namun, semua itu dikembalikan kepada si pengguna internet yang menggunakan internet untuk hal positif atau negatif. 


\section{2 .STUDI LITERATUR}

Dalam literature akademis banyak yang dapat dikatakan sebagai media baru (new media). Dalam pengucapannya new media menunjuk kepada ciri-ciri dan juga kepada teknologinya. Tetapi, dasarnya banyak pengucapan itu memiliki sumber yang mirip, yaitu menunjuk kepada perangkat media baik itu hardware atau software.

Kemunculan media interaktif bisa dikatakan sebagai struktur kedua dari karakteristik media baru. Di era media interaktif, khalayak dimungkinkan untuk melakukan umpan balik langsung dan bahkan adanya transformasi dari batasan antara khalayak dan produsen informasi; bahwa khalayak di era media interaktif bisa menjadi konsumen dan saat itu juga menjadi produsen dari informasi. Realitas virtual ini dijelaskan melalui empat level pendekatan . Pertama, media interaktif memungkinkan komunikasi banyak pihak atau multilateral communication. Level ini menandakan dimensi ruang yang ditawarkan Oleh media digital yang bisa melibatkan banyak pengguna secara bersamaan. Kedua, terjadinya sinkronisasi bahwa media interaktif dalam dimensi waktu ini menunjukkan inter- aksi antar-pengguna yang bisa dilakukan, baik melalui waktu yang sama maupun pengguna bebas menentukan sendiri waktu komunikasi tanpa menghilangkan atau menghambat proses komunikasi itu sendiri, misalnya dalam e-mail. Ketiga, terjadinya keleluasaan kontrol dari para pengguna yang melakukan interaksi. Ini merupakan dimensi kebiasaan (behavioral) di mana para pihak di media Siber Iidak lagi dibalasi Oleh siapa yang sender dan siapa receiver, kedua fungsi ini bisa ditukar posisi dalam proses interaksi. Keempar, pada level ini proses interaksi sejalan dengan pemahaman terhadap makna dan konteks yang melibatkan para pengguna. Ini yang disebut dengan level tertinggi, yakni terkait dengan dimensi mental. Meski secara teknis setiap khalayak yang memiliki koneksi ke internet ia akan masuk dalam jejaring dan terhubung, namun dalam komunikasi termediasi komputer selalu saja ada bahasa universal, misalnya penggunaan emoticons atau ekspresi diri di dunia Siber dalam percakapan atau komunikasi yang diekspresikan melalui teks, simbol atau lambang, yang harus dipahami. Ketika empat level atau dimensi ini muncul, maka pada Saat itulah apa yang disebut interaksi di media baru itu terjadi.

Membicarakan soal media interaktif di internet (media baru) tidak hanya membahas tentang perangkat lunak saja, namun juga melibatkan beberapa aspek semua penggunanya. Suatu perangkat dapat berjalan sesuai prosedur yang telah ditetapkan, penggunalah yang akhirnya akan memilih peroses komunikasi melalui perangkat itu. Tidak berarti bahwa berkomunikasi langsung menjadi tidak efisien dan efektif, tetapi dengan media baru adalah cara membawa komunikasi langsung beserta aspek dan semua hal di dalamnya menuju komunikasi yang lebih termediasi. 


\section{3 .METODE PENELITIAN}

Pnelitian yang digunakan dalam menyusun artikel ini adalah dengan menggunakan metode literature dan library research.Penelitian dengan metode kepustakaan ini yaitu penelitian yang bersumber dari beragam literature perpustakaan baik berupa buku, jurnal, kamus, dokumen, dan lainnya. Sehingga dapat ditemukan, diungkapkan, dikembangkan dan diuji kebbenaran suatu konsep, teori, dan pemikiran seorang tokoh. Penelitian ini juga menggunakan sumber data sekunder seperti jurnal, website, dan buku-buku yang berkaitan.

\section{4 .PEMBAHASAN}

\section{A. Media Dalam Persfektip Historis}

Perkembangan media ini bisa ditelusuri dari Sisi sejarah media maupun teknologi komunikasi yang mempengaruhi perubahan sosial. Dapat dikatakan selama masyarakat melakukan praktek komunikasi, media tidak ada matinya. Dalam perspektif historis, argumen lain dapat dikedepankan untuk menjelaskan mengapa manusia selalu memerlukan media ialah pada fungsi media yang strategis.

Dengan keberadaan media berbagai informasi bisa didapatkan masyarakat. Pada posisi ini, media dapat menjadi perpanjangan atau ekstensi indera manusia. Media menjadi perpanjangan panca indera manusia yang mencerap berbagai informasi di lingkungan sekitar, untuk berbagai aktivitas sehari- hari (McLuhan, 1964), Terlebih pada era mediasi seperti saat ini, nyaris tidak mungkin manusia bisa melepaskan diri sepenuhnya dari media.

Struktur sosial masyarakat modern yang menempatkan media sebagai bagian sentral dalam kehidupan, seperti yang termanifestasikan pada kondisi sekarang ini menjadikan media memiliki potensi yang amat strategis. Andai media secara terlembaga dapat dikelola dengan baik, tentu manfaat dan fungsi media bagi masyarakat semakin besar. Masyarakat bisa mendapatkan banyak faedah dari media. Hal ini bisa dipahami dari pengertian media yang secara mendasar merupakan pembawa informasi.

Mengacu kepada KBBI (1990), media dapat dimengerti dari pengertian secara murni yang memiliki arti: alat, sarana komunikasi, perantara, dan penghubung. Bertolak dari definisi ini, secara eksplisit terdapat beberapa jenis media yang berkembang saat ini. Sedangkan media massa merupakan Sarana formal sebagai perlengkapan agar berita tersebar secara merata kepada masyarakat luas (Kamus Besar Bahasa Indonesia, 1990, h. 569). Bentuk dari media pada Saat ini sudah sangat beragam. Setidaknya terdapat media cetak, media elektronik. serta new media dengan sejumlah tipologinya (McQuail, 2010). Dari pemahaman mengenai media ini, salah satu aspek yang perlu dioptimalkan ialah bahwa media memiliki kekuatan yang unik, yaitu bisa membuat berita tersebar 
secara bersamaan. Kekuatan yang unik ini kemudian diperdaya oleh banyak orang untuk kepentingan pribadinya. Para aktor politik memanfaatkan media untuk meraih simpati warga. Pengusaha memakai media untuk promosi. Konsultan PR menggunakan media untuk pencitraan, termasuk para akademisi juga memanfaatkan media sebagai Sarana menyebarkan gagasaan.

Mengenai optimalisasi penggunaan media ini, antara lain bisa dibaca dalam sejumlah literatur, antara lain dalam buku Mixed Media: Moral Distinction in Advertising, Public Relations and Journalism. Karya Thomas H. Bivins, serta Journalism and New Media karya John V. Pavlik. Dari paparan studi mengenai media tersebut, secara praktis implementatif nilai kebermanfaatan media yang ternyata amat luas telah menjadikan media sebagai "bidang" sekaligus wahana yang terus berkembang. Menariknya, perkembangan ini ternyata berbanding lurus dengan kajian teoritik terhadap jurnalisme dan media yang juga mengalami perkembangan signifikan. Di sejumlah Universitas, kajian terhadap jurnalisme dan media mendapatkan perhatian besar dari akademisi di berbagai strata, baik Strata-I (Sarjana), Strata-2 (Master). maupun Strata-3 (Doktor). Hal ini terlihat dari banyaknya penelitian-penelitian yang mencermati pemberitaan media dalam berbagai konteksnya, mulai dari konteks politik, sosial, ekonomi, maupun budaya. Bila ditinjau dari alur historisnya, kebermanfaatan media telah dikaji cukup lama. Setidaknya mulai dikembangkan semenjak abad 19. Bila dihitung dari awal kalian jurnalisme secara formal pada sejumlah universitas di Amerika, yakni sekitar tahun 1900.

Pada tahap berikutnya, bidang kalian yang menempatkan media sebagai Objek kalian mengalami kemajuan. Di barat, dinamika dan praktik jurnalisme dan media, mulai dikaji secara intensif Oleh para penulis, pemikir, dan jurnalis seperti Walter Lippmann, Harold D. Lasswell, termasuk Everett M. Rogers. Tercatat, misalnya, Walter Lippmann menulis buku terkenal berjudul Public Opinion yang pertama terbit tahun 1922, yang kemudian menjadi literatur klasik bagi studi-studi tentang propaganda. Problem kunci yang dikemukakan Lippmann di buku ini antara lain bahwasannya publik tidak melihat fakta yang sesungguhnya, namun apa yang mereka terima melalui media sebagai fakta. Artinya, realitas yang dimunculkan media, bukan realitas sesungguhnya, tetapi sudah merupakan lingkungan semu (pseudo environment).

Sementara itu orang cenderung percaya pada gambaran yang ada di kepalanya. Pada kenyataannya, kecenderungan yang dikemukakan Lippmann tersebut lebih dari 8 dekade lalu ini ternyata masih relevan sampai sekarang. Tidak hanya itu, sebagai seorang jurnalis politik. tokoh yang banyak dipengaruhi oleh William James. George Santayana, dan Graham Wallas ini, dikenal luas sebagai tokoh bidang Jurnalisme di tengah publik abad 21 . Perhatiannya mencakup sejumlah bidang seperti filsafat publik. demokrasi, politik, masalah ekonomi, serta masalah kebijakan luar negeri. 
Pada kurun waktu tahun 1889-1974. tulisan-tulisan Lippmann mengalir sangat deras. la mengelaborasi peristiwa nasional dan kejadian di berbagai belahan dunia. Hal yang menarik. tulisan-tulisan Lippman telah mendapatkan perhatian yang luas dari masyarakat. Khususnya mengenai opini publik dan propaganda politik, serta aksi media modern dalam mengabarkan suatu peristiwa. Lebih jauh lagi, pada dasarnya studi mengenai propaganda dan opini publik merupakan dasar teori agenda setting. Isu-isu populer yang berhasil menarik perhatian khalayak menuniukkan kemampuan media untuk memilah dan memilih, serta menonjolkan sekaligus menenggelamkan suatu isu atau peristiwa. padahal munculnya isu tersebut merupakan hasil konstruksi yang dikembangkan media secara terstruktur. Dengan kata lain, boleh dikata pemikiran dari Walter Lippman yang mendasari perumusan teori agenda setting. Lebih tepatnya sebelum agenda setting dirumuskan Oleh Maxwell E. Mc Combs dan Donald Shaw.

Di samping Walter Lippmann. sosok Harold Dwight Lasswell di awal abad 20 juga berpengaruh kuat dalam studi media, propaganda, dan politik. Selain merupakan ilmuwan politik terkemuka di Amerika Serikat, Harold D. Lasswell, bersama dengan tokoh seperti Kurt Lewin, Paul Lazarsfeld, dan Carl 1. Hovland, merupakan tokoh yang mempengaruhi perkembangan ilmu komunikasi di dunia.

Salah satu gagasan Lasswell yang fenomenal ialah model komunikasi Who Says What in Which Channel to Whom With What Effect Model ini merupakan model komunikasi yang amat awal dikenal dan paling banyak dikutip oleh para pembelaiar ilmu komunikasi sampai Saat ini. Melalui elaborasi teoritiknya, komunikasi yang dikemas dengan simbol-simbol memiliki kekuatan besar. Komunikasi dapat digunakan sebagai teknik propaganda yang dapat memobilisasi persepsi khalayak secara massal.

Berdasarkan paparan ini tampak jelas bahwa media memiliki cakupan kegunaan yang luas. Kebermanfaatan dan fungsi media tidak hanya untuk warga di level masyarakat bawah, tetapi juga level menengah dan level atas. Manfaat media bahkan tidak hanya untuk bidang jurnalistik semata tetapi juga bidang lain. Terutama bidang yang juga berkembang di dunia profesional komunikasi seperti public relations, broadcasting, advertising, maupun marketing. Cermatan komprehensif mengenai hal ini, lebih lanjut bisa dibaca dalam buku karya Thomas H. Bivins yang berjudul Mixed Media: Morul Disctinctions in Advertising, Public Relations, and Journalism.

Melihat munculnva beberapa topik kalian yang kontekstual seperti di atas. secara eksplisit menunjukkan adanya peningkatan trend kajian ilmu komunikasi secara global. Secara umum, kajian-kajian itu memosisikan ilmu komunikasi sebagai sains yang bisa diterapkan di bidang industri. Tidak hanya itu dalam perkembangannya. ilmu komunikasi dapat melintas batas. pada satu Sisi ilmu komunikasi tampil sebagai ilmu yang bercorak terapan, meski tidak dipungkiri pula, dengan kalian filsafat, sejarah sosial, maupun biografi intelektual para founding Lathers ilmu komunikasi, telah memosisikan pula ilmu komunikasi sebagai ilmu saintifik yang bercorak teoritis. 
Dalam konteks Indonesia, kalian terhadap fenomena komunikasi, yang bercorak teoritis juga berkembang pesat. perkembangan itu terutama setelah ranah profesi dalam industri komunikasi semakin maju. Tidak sedikit sarjana ilmu komunikasi yang menjadi praktisi, namun tidak sedikit pula yang meniadi teoritisi. Ada pula yang bergerak dalam track keduanya, dual track, menjadi teoritisi sekaligus praktisi. Sesuai dengan karakteristik ilmu komunikasi yang di satu Sisi merupakan pure science, tetapi sekaligus applied science.

Corak kajian yang lebih teoritis, seperti teori-teori yang mengulas tentang penyampaian, pemrosesan, dan dampak suatu pesan dalam ilmu komunikasi mendapat perhatian besar. Dengan perkataan lain. studi pesan secara tekstual dan kontekstual meniadi daya tarik tersendiri. Ini terlihat dari teori yang dikembangkan para akademisi di bidang ilmu komunikasi merentang amat luas pada teori-teori komunikasi yang menyigi dan mendedah bagaimana suatu pesan dikelola. lames Curran, misalnya, menyebut bidang jurnalisme, media, dan sejarah komunikasi berkembang tidak hanya di Amerika Utara dan Eropa.

Pada kenyataannya Saat ini, ilmu komunikasi telah menyebar di Asia. Australia. maupun Afrika Peluang perkembangannya juga cukup besar sejalan dengan cepat berkembangnya teknologi informasi dan komunikasi. Terlebih pada zaman yang semakin global seperti sekarang informasi merupakan modal utama. Pada konteks ini, informasi dapat dengan mudah diterima masyarakat dengan adanya media. Di dalamnya, peran fundamental media ialah menjadi pembawa pesan atau malah menjadi "pesan" atau medium itu sendiri. Konsep medium pada mulanya dikembangkan dari karya Harold Innis dan Marshall McLuhan dalam menggambarkan pergeseran media dalam menyampaikan pengalaman atau perilaku manusia Artinya, dalam proses komunikasi. media merupakan wahana pelengkap paling pokok dalam penyampaian informasi atau kabar tertentu.

Bila kita retrospeksi sejenak ke era tahun 1970-an atau 1980-an, tentu pada saat itu belum berkembang media online, sehingga ritme kerja para jurnalis yang meliput berita relatif lebih longgar. pola penyampaian informasi juga relatif lebih lambat jika dikomparasikan dengan laju informasi Saat ini. Bila sebelumnya, penyampaian berita, gambar, atau pesan dari luar negeri baru sampai setelah satu hari, atau satu minggu. Pada Saat ini, sebuah pesan bisa tersampaikan secara serempak dalam hitungan menit bahkan detik. Berkat kelebihan pada kecepatan, new media bisa menjadi alternatif bagi pencari informasi terbaru. Kelebihannya adalah nyaris semua informasi tersedia dan bisa diakses sangat mudah lewat new media. pendeknya, mengetahui seluk beluk metode mengakses new media menjadi bermanfaat.

\section{B. PEMBERDAYAAN NEW MEDIA PADA BERBAGAI SISI}

a.Dari Sisi Politik 
Jejaring sosial merupakan contoh new media yang sering digunakan tokoh politik diIndonesia maupun diluar Indonesia. Salah satu contoh yang paling banyak digunakan itu facebook, instagram, twiter, dan sosial media lainnya. Pada tahun 2009 calon presiden dan wakil presiden yaitu Prabowo Subianto memperdayakan sosial media untuk mendapatkan banyak dukugan. Karena itu Prabowo mendapatkan banyak teman sehingga facebook memperingatinya dengan memberi notifikasi dari facebook. Selain itu Calon Presiden pada tahun ini memnggunakan old media yaitu dengan mempromosikan diri melalui iklan, majalah, Koran, spanduk dan lain-lain.

Pemberdayaan internet juga dirasakan orang yang berada diluar Indonesia seperti Barack Obama pada tahun 2008. Dalam buku yang berjudul communicator in Chief: How Barack Obama Used Media Technology to Win the White House menyatakan bahwa untuk kampaye Barack Obama menggunakan mengoperasikan lebih dari 150.000 kegiatan, 35.000 kelompok dan membuat 1.500 .000 akun di internet untuk mendapatkan USD 600 juta. Selain itu Barack Obama menggunakan facebook dan Myspace untuk mempromosikan diri. Dengan usahanya ini Barack Obama dapat menjadi pemimpin di Amerika dikarenakan pemberdaaan new media yang bagus.

Degan new media, berita tentang perpolitikan sudah dengan mudah kita temui di situs atau web yang bersangkutan dengan politik, dengan hal ini politik telah memanfaatkan internet sebagai media untuk mempromosikan diri agar masyarakat dapat mendukung atau menerima suatu yang ditetapkan oleh politik. Akan tetapi, banyak orang yang membahas tentang politik disebuah situs dengan cara setengah-setengah, hal ini dapat membuat pembaca situs ini salah mengartikan maksud apa yang disampaikan suatu politik yang membuat pembaca salah paham akan arti yang ingin diungkapkan. Oleh sebab itu berita hoax menjadi marak dizaman ini dikarenakan banyak yang tidak malu menyebarkan suatu berita palsu mengenai suatu politik. Hal ini akan berakibat buruk untuk politik dan masyarakat. Karena itu kita harus menyelidiki terlebih dahulu kebenaran suatu situs atau web.

\section{b. Dari Sisi Ekonomi}

Media berbasis web ada dalam berbagai struktur, termasuk organisasi informal, pertemuan web, weblog, jurnal online sosial, tulisan mini untuk blog, wiki, rekaman web, gambar, rekaman, evaluasi, dan bookmark sosial. (, Kaplan dan Haenlein 2010) merekomendasikan bahwa ada enam jenis media berbasis web: tugas kooperatif (misalnya wikipedia), situs dan mikroblog (misalnya twitter), korespondensi konten (misalnya youtube), lokal komunikasi interpersonal jarak jauh (misalnya facebook), game virtual (misalnya ekspresi warcraft), dan sosial virtual (misalnya kehidupan kedua). 
Interaksi interpersonal adalah situs web di mana setiap orang dapat membuat halaman individual, kemudian bergabung dengan teman untuk berbagi informasi dan berbagi. Organisasi antarpribadi terbesar menggabungkan facebook, myspace, plurk, dan twitter. Dengan asumsi media konvensional memanfaatkan media cetak dan media penyiaran, media online memanfaatkan web. Media online menyambut setiap individu yang tertarik untuk tertarik dengan memberikan kontribusi dan masukan secara transparan, memberikan komentar, dan berbagi data dalam waktu yang cepat dan tanpa batas.

Seiring berkembangnya inovasi web dan ponsel, media online juga berkembang pesat. Saat ini untuk mengakses facebook, twitter atau instagram misalnya, cenderung dilakukan dimana saja dan kapan saja hanya dengan memanfaatkan ponsel dan organisasi web. Seberapa cepat individu dapat mengakses media berbasis web telah membawa keajaiban besar dalam perkembangan data di negara-negara maju, tetapi juga di Indonesia. Karena kecepatannya, media berbasis web juga tampaknya mulai menggantikan pekerjaan komunikasi luas yang teratur dalam menyebarkan berita.

Iklan media online terdiri dari penggunaan media berbasis web untuk meyakinkan pembeli tentang produk dan administrasi suatu organisasi. Penayangan media berbasis web adalah periklanan yang memanfaatkan jaringan web, organisasi informal, mempromosikan jurnal online dan langit adalah batas dari sana. Salah satu ilustrasi pemanfaatan media baru di web adalah toko online di Instagram.

- Toko online di instagram

Toko online di media web instagram adalah toko belanja berbasis web yang terletak di organisasi web, khususnya media berbasis web instagram, dan setelah itu ada latihan jual beli internet.

Sebelumnya, Instagram hanya dimanfaatkan sebagai media kekinian/media narsis. Saat ini, bisnis online semakin tidak terbatas, sehingga Instagram dipenuhi dengan berbagai jenis toko online. Instagram saat ini tidak hanya digunakan untuk para individu yang menyukai fotografi atau foto-foto saja. Bagaimanapun, Instagram adalah alat yang berguna untuk mempromosikan suatu produk agar lebih dikenal secara umum. Berbisnis online shop di Instagram seharusnya bisa dilakukan oleh siapa saja dan dimana saja karena hanya memiliki alat dan ponsel berbasis Android, iOS, bahkan Windows Phone.

Pelaku bisnis online mengaku lebih mudah memasarkan produknya melalui Instagram karena sasaran pertama adalah orang yang paling dekat dengannya, bisa juga melalui teman yang awalnya dari mulut ke mulut sambil menunjukan akun Instagram, komunikasi tersebut sangat efektif bagi para penjual, dengan adanya media Instagram semakin mudahnya penjual menunjukkan foto atau katalaog barang jualannya. Dalam hal ini secara tidak langsung proses tersebut membentuk suatu rangkaian komunikasi pemasaran. 
Ahli keuangan online menjamin bahwa lebih mudah untuk mengiklankan barang mereka melalui Instagram karena tujuan utamanya adalah orang terdekat mereka, bisa juga melalui teman yang pada awalnya mengatakan dengan mendengar percakapan orang sambil menunjukkan akun Instagram, korespondensi ini menarik bagi dealer, dengan media instagram lebih mudah bagi merchant Menampilkan foto atau daftar barang dagangan yang dijual. Untuk situasi ini, interaksi secara tidak langsung membentuk perkembangan menunjukkan korespondensi.

Manfaat khusus dari toko online yang memanfaatkan media Instagram adalah pasar yang teredukasi inovasi. Salah satu keuntungan berjualan melalui Instagram adalah klien Instagram kini 'ditakdirkan' untuk menjadi ahli inovasi. Artinya, individu yang dinamis di Instagram juga harus dinamis di Twitter dan mungkin juga Facebook. Oleh karena itu, sudah selayaknya untuk memajukan produk melalui Instagram dan dibantu oleh organisasi informal lainnya, pengguna Instagram harus memiliki perangkat mahal dan ponsel yang mendukung aplikasi seperti iPhone, ini berarti Instagram memiliki pelanggan yang berada di kelas atas biasa. Ini bermanfaat bagi vendor, karena kemungkinan klien atau pembeli mungkin akan memiliki sumber daya yang melimpah.

\section{c. Dari Sisi Pendidikan}

Di samping sebagai pembawa informasi yang akurat, media juga berfungsi sebagai pendidik masyarakat. Dalam hal ini, Wilbur Schramm semenjak empat dekade yang lalu sudah mengemukakan media dapat digunakan untuk sarana mendidik. Media instruksional yang banyak digunakan untuk mendidik dalam hal ini, menurut Schramm, yang banyak digunakan adalah media elektronik dan fotografik. Bentuknya bisa berupa foto, slide, film, rekaman, radio, televisi dan komputer. Hingga saat ini, dengan akses luas dan terbuka, media bisa menjadi guru bagi siapa saja yang membutuhkan.

Mirip seperti halnya buku, media juga bisa menjadi guru yang amat sabar. Bagi individu yang cermat, banyak materi dari media yang bisa dikembangkan dan dianalisis. Mulai dari rubrik pendidikan, hukum, politik. otomotif, sosial, budaya, olahraga, kriminal termasuk kolom opini, merupakan kumpulan wawasan, dan ilmu pengetahuan. Di tengah sumber-sumber daya yang dapat dimanfaatkan oleh manusia, kekuatan media terletak pada aktualitas informasinya. Argumentasinya ialah semua masalah paling aktual, selalu muncul di media. Hanya saja, kebermanfaatan media sebagai pendidik, akhirnya tetap kembali kepada individu, yakni bagaimana sebuah media sebagai sumber informasi dapat termanfaatkan secara optimal. Idealnya, media dengan muatan informasinya dapat mencerdaskan masyarakat. Dalam sistem komunikasi massa yang sehat. karakter media mendidik ialah adanya bentuk penyampaian informasi yang aktual dan menghibur. Dalam keadaan begitu, media juga menjalankan fungsinya sebagai ajang penyegaran otak Dengan demikian, sebuah media idealnya tidak hanya memuat 
berita buruk dan negatif, tetapi juga berita positif yang bisa mendorong, menghibur, dan menginspirasi masyarakat Indonesia untuk berwawasan lebih luas. Perkaranya ialah gerak dan perilaku media tidak selalu demikian. Malahan yang justru menjadi kecenderungan utama adalah aksi media yang cenderung liberal, bebas, menjadikan peristiwa apapun yang dinilai menarik untuk diangkat menjadi berita.

Untuk mengantisipasinya, diperlukan sosialisasi media literasi yang memadai. Media literasi merupakan pernahaman komprehensif dan kemampuan untuk mengakses, menganalisis, mengevaluasi, dan memproduksi konten baik untuk media cetak maupun elektronik Dengan pernahaman mendasar mengenai media literasi, masyarakat dengan sendirinya akan terlatih dan terdidik untuk mempertanyakan secara memadai ada apa di balik produksi konten media? Adakah motif tertentu? Nilai uang, komodifikasi, atau faktor kepemilikan yang lebih dominan? Jawaban mandiri terhadap pertanyaanpertanyaan mendasar ini diharapkan bisa memberikan gambaran menyeluruh mengenai faktor internal dan eksternal yang dapat mempengaruhi hadirnya sebuah konten media.

Dengan mengajukan pertanyaan-pertanyaan di atas terhadap tayangan media, secara bertahap masyarakat menjadi kritis. Kuncinya memahami konstruksi isi pesan media. Bila dibiasakan mengajukan pertanyaan-pertanyaan seperti di atas, seorang penikmat media bisa mengembangkan diri menjadi pengamat media. Pada kondisi demikian, idealnya pembaca media tidak hanya menikmati sajian media, tapi juga mengamati mengapa hal itu bisa terjadi? Apalagi di negara berkembang seperti Indonesia yang di dalamnya media massa berkembang dengan pesat, maka pencermatan terhadap apa dan bagaimana media bekerja menjadi penting terutama untuk kemaslahatan publik. Betapapun faktor pemilik dan afiliasi sebuah media terhadap organisasi atau partai politik juga dapat mempengaruhi sajian isi media.

Bila demikian halnya, maka publik sebagai konsumen berita media senantiasa perlu memperhatikan konteks sosial yang mempengaruhi sebuah media. Problemnya bukan hanya materi berita. tapi juga konteks struktural dan kultural di sekitar media. Bisa kita rasakan bersama, dalam iklim media sekarang bauran antara representasi dan realitas seringkali sulit dibedakan. Banyak info Hoax. Mana benar mana salah kerap tidak jelas. Banyak contoh tayangan infotainment, sinetron yang mengumbar unsur sensualitas, juga sinetron klenik plus takhayul yang bila tidak difilter dengan literasi yang cukup, juga bisa menjadi masalah pelik bagi kalangan masyarakat akar rumput yang mudah dipengaruhi oleh informasi dari sumber yang tidak kredibel.

Gejala seperti ini merupakan ekses negatif dari tebaran isi media yang diumbar penayangannya tanpa kontrol. Tantangan bagi pembaca media menjadi semakin jelas: berbagai informasi menjadi lebih sulit untuk diverifikasi. Nyaris semua media, terutama media elektornik, terjangkiti kecenderungan yang sebenarnya kontra-produktif, karena banyak informasi yang tidak jelas asal-usulnya. 
Namun demikian bila dilihat dari Sisi positifnya, sebenarnya media juga bisa menjadi kawan bagi pengaksesnya, sekaligus juga sebagai kontrol sosial politik terhadap pihak penguasa. Media dapat menjadi sarana pembelajaran efektif, misalnya saja untuk pendidikan politik bagi kalangan mahasiswa (Hamad, 2001: 57). Pertimbangan perlunya pendidikan melalui media ini, menimbang begitu banyaknya kandungan informasi dalam media yang bisa dikembangkan. Hampir Semua isu dan peristiwa terkini, selalu muncul di media massa, Syaratnya ialah kesabaran dan kepekaan dalam mencermati sajian media.

\section{5 .KESIMPULAN}

Dalam pembahasan dikemukakan bahwa internet menjadi media baru yang paling diminati dan dimanfaatkan oleh dunia. Hal tersebut terjadi karena dua sebab, yang pertama disebabkan banyaknya pengguna internet didunia yang diperkirakan pada tahun 2011 mencapai 2 milyar orang sudah menggunakan internet, dan yang kedua disebabkan banyaknya fitur aplikasi yang ditawarkan internet menjadikan banyak peminat dari media baru ini.

Ilmu pengetahuan sekarang telah memanfaatkan internet olehkarena itu internet berkaitan dengan banyak bidang dikehidupan manusia. dalam tulisan kali ini pemanfaatan internet dibatasi dalam bidang politik, bisnis, dan pendidikan saja. Hal ini ditimbangkan karena berbgai new media yang ada diinternet semuanya banyak digunakan dan dimanfaatkan oleh ketiga bidang ini.pemanfaatan yang dimaksud adalah pemanfaatan yang positif walaupun dalam prakteknya internet digunakan juga untuk tujuan yang negative oleh sebagian kecil pengguna internet.

Internet merupakan bagian dari teknologi informasi yang terus akan berkembang sebagaimana yang sudah terjadi selama ini. Di masa depan pasti akan muncul new media yang akan menggantikan media yang ada sekarang yang nantinya akan bergeser sebagai old media. Siklus seperti ini akan terjadi selama peradaban manusia dengan Internetnya masih berlangsung. 


\section{Daftar Rujukan}

Andreas, Kaplan Michael (2010). User of The World, Unite The Challenges and Opportunities of Social Media. Business Horizon.

Cheng, Chung Tai. 2009. New Media and Event a Case Study on the Power of the Internet. Vol.22.

Fikri, Muhmmad,2018.'Sejarah Media Transformasi,pemanfaatan,dan tantangan”. Malang : UB Press.

Flew, Terry. 2005. New Media. Oxford University Press

Hamad, 2004 _ Konstruksi Realitas Politik di Media Massa sebuah Study Critical Discourse Discourse. Jakarta: Granit

Jarvis, Sharon E. 2010. Communication in Chief How Barrack Obama Used New Media Technology to Win the White House. Presidential Studies Quarterly, Vol. 40 Iss 4

Littlejohn, Stephen W \& Karen A. Foss.2009. “Teori Komunikasi edisi 9”.Jakarta: Salemba Humanika

McQuail, Dennis and Sven Windahl. 1996. Com, munication Models - for The Study of Mass Communication. New York: Longman.

Marshall McLuhan.”196.Understanding Media The Extensions of Man”. CHAPTER 1

Nasrullah,Rulli.2014.’Teori Dan Riset Media Siber (Syber media)”. Jakarta :

PRENADA MEDIA GROUP. 
Riaz, Saqib. 2010. "Effects of New Media Technologies on Political Communication". Journal of Political Studies, Vol.1 Iss.2. 